Purdue University

Purdue e-Pubs

$1-1-1993$

\title{
Information and Normal Backwardation as Determinants of Trading Performance: Evidence from the North-Sea Oil Forward Market
}

Gordon M. Phillips

Purdue University

Robert J. Weiner

Harvard University

Follow this and additional works at: http:// docs.lib.purdue.edu/ciberwp

Phillips, Gordon M. and Weiner, Robert J., "Information and Normal Backwardation as Determinants of Trading Performance: Evidence from the North-Sea Oil Forward Market" (1993). Purdue CIBER Working Papers. Paper 68. http://docs.lib.purdue.edu/ciberwp/68

This document has been made available through Purdue e-Pubs, a service of the Purdue University Libraries. Please contact epubs@purdue.edu for additional information. 


\title{
INFORMATION AND NORMAL BACKWARDATION AS DETERMINANTS OF TRADING PERFORMANCE: \\ Evidence from the North-Sea Oil Forward Market
}

\author{
Gordon M. Phillips \\ and \\ Robert J. Weiner
}

93-101

Center for International Business Education and Research

Purdue University

Krannert Graduate School of Management

1310 Krannert Building

West Lafayette, IN 47907-1310

Phone: (317) 494-4463

Fax: (317) 494-9658 


\title{
INFORMATION AND NORMAL BACKWARDATION AS DETERMINANTS OF TRADING PERFORMANCE:
}

Evidence from the North-Sea 011 Forward Market

Gordon M. Phillips

Krannert School of Management

Purdue University

\author{
Robert J. Weiner \\ Business-Government Center \\ John F. Kennedy School of Government \\ Harvard University
}

and

GREEN, Département d'économique

Université Laval

Revised June 1993

We thank Shantayanan Devarajan, Kathryn Dominguez, Michael Hartzmark, Ked Hogan, Craig Lewis, John Meyer, Eric Sirri, an anonymous referee, and participants at the Academy of International Business, European International Business Association, and American Finance Association annual meetings, and in seminars at the Chr. Michelsens Institutt, Bergen, the Ecole des HEC, Montréal, the National Bureau of Economic Research, Boston College, Boston University, MIT, and the "Journees du GREEN," Université Laval, for comments; the Columbia Futures Center and the Harvard-Japan Program on Energy and the Environment for support; and Petroleum Argus for data. Responsibility for the contents of the paper is solely ours. 


\section{INFORMATION AND NORMAL BACKWARDATION AS DETERMINANTS OF TRADING PERFORMANCE: \\ Evidence from the North-Sea 0 il Forward Market}

\section{Abstract}

In this paper we take advantage of a unique micro-database on forward trading in the international petroleum market, with information on the buyer and seller in each transaction. We utilize transaction-specific data to test directly predictions from the theory of normal backwardation vs. information-based predictions of who profits in these markets.

We find that no trader groups make significant profits on interday measures. Within the day, however, groups likely to have superior information do make significant profits. The results are not supportive of normal backwardation, but are consistent with the time pattern of information dissemination in this market-deals made during the day are widely reported only at day's end. 


\section{INFORMATION AND NORMAL BACKMARDATION AS DËTERMINANTS OF TRADING PERFORMANCE:}

\section{Evidence from the North-Sea 011 Forward Market}

Resolution of the longstanding debate over who gains and who loses in financial markets requires data at a disaggregated level. In this paper we take advantage of a unique database with information on the buyer and seller in each transaction in a forward market to measure trading performance. Our tests are designed to shed 1 ight on the potential sources of differential returns to participants in forward and futures markets. We examine trading performance to assess the empirical relevance of two potential sources of differential returns: insurance and information.

Behind the insurance view is the theory of "normal backwardation," dating back to feynes (1930) and Hicks (1946). The theory treats these markets as arenas wherein risk-averse "hedgers," firms that produce or utilise the physical commodity, purchase insurance from "speculators," who do not. Until the 1980s, the bulk of the research literature on forward and futures markets was based on the norma1backwardation assumption (see, e.g., Kawai 1983).1

An alternative (but not mutually exclusive) explanation of trader performance is based on information. That differential information can affect prices and profits in financial markets has been demonstrated formally in recent research (e.g., Grossman and Stiglitz 1980, Kyle 1985). A literature has developed based on asymmetrically-informed market participants, with the less-informed referred to as "noise traders."2

\footnotetext{
The literature outside this tradition (e.g.. Telser and Higginbotham 1977. Telser 1981, Williams 1987). in contrast, is relatively fragmented and sparse.

${ }^{2}$ Shleifer and Summers (1990) provide an overview of this literature.
} 


\section{DETERMINANTS OF TRADING PERFORMANCE, page 2}

The classic theory of normal backwardation yields the testable hypothesis that, on average, speculators should gain and hedgers should lose in these markets. More recently, a literature based on portfolio theory (e.g., the Capital Asset Pricing Model) has pointed out that the traditional normal-backwardation approach implicitly assumes that cläims on hedgers' profits (e.g.; equity) cannot be marketed costlessiy. Models based on the opposite assumption--that forward and futures markets are perfectly integrated with markets for other assets--yield the conclusion that risk premia are not related to hedging, because speculators can costlessiy enter futures and forward markets, and diversify the nonsystematic risk assumed in these markets by combining them in portfolios with other assets. ${ }^{3}$

Hirshleifer (1988) integrates the traditional theories of risk premia based on hedging with the portfolio approach, demonstrating that nonmarketability of claims on profits, together with fixed costs of entering asset markets, yield predictions similar to those of the simple normal-backwardation model. Bessembinder (1992) uses monthly aggregate data from a variety of futures markets to test these predictions against those of the portfolio approach. He finds support for Hirshleifer's modern version of the normal-backwardation model, in that net hedging, interacted with residual risk, is associated with returns in futures markets.

In contrast, the asymmetric-information view of trader performance predicts that traders with better information will gain at the expense of uninformed or "noise" traders. Thus, if traders who operate in the cash (physicals) market have superior information about future supply and demand conditions, the prediction of the normal-backwardation model can be reversed.

\footnotetext{
${ }^{3}$ Dusak (1973) was the first to attempt to relate returns on futures contracts and the systematic risk emphasized in portfolio theory, finding no significant relationship.
} 
Typically, though, the only data that are publicly available are prices and market volumes; thus, transactions by hedgers and speculators have not been distinguished. Faced with this obstacle, economists have fallen back on attempting to detect risk premia in price data, as evidence of the insurance fees predicted by normal backwardation. In contrast, our information on the parties to and terms of each trade allows a direct test of the role of these two potential sources of differential trading performance. We construct trading accounts for each type of company in the database, and use these accounts to test whether hedgers lose and speculators gain in this market.

Recent papers by Hartzmark $(1987,1991)$ are the only other attempt to utilise information on individual traders to test whether on average speculators gain and hedgers lose in these markets. Hartzmark's data, disaggregated by individual $\underline{\text { trader }}$ rather than individual trade, do not support the normal-backwardation theory. ${ }^{4}$ In contrast, empirical studies based on aggregate data have found support for the normal backwardation theory (e.g., Chang 1985). 5 These studies, like Hartzmark's, were obliged to rely on data from U.S. markets, as well as on the arbitrary definition of "large" used by the U.S. Commodity Futures Trading Commission (CFTC). 6

\footnotetext{
${ }^{4}$ Utilising end-of-day position data in nine futures markets. Hartzmark finds that large hedgers actually make significantly positive (at the $5 \%$ level) returns overall. while large speculators' returns differed insignificantly from zero. Large hedgers' returns were positive in eight of the nine markets.

${ }^{5}$ Hartzmark $(1987,1991)$ are the only papers employing disaggregated data. The pioneering paper by Houthakker (1957). as well as the very few other empirical studies in this literature (e.g.. Bessembinder 1992: see Hartzmark 1987 for citations) have relied on data that were highly aggregated over traders. time. or both.

6 The data used in previous studies come from the CFTC, which requires "large traders" (the threshold number of contracts for "large" depends on the commodity) to report their positions daily, and to identify these positions as "commercial" (i.e.. there were offsetting comitments in the cash market) or non-commercial (no offsetting comitments). Below the regulatory threshold, traders are considered "small" and are not required to report their positions to the CFTC. A given firm can change categories based on its behaviour in a given month, or on the periodic changes in the thresholds. In the aggregate studies, as well as Hartzmark's, small traders are treated as a residual, and assumed to be speculators. As futures trading is a zero-sum game, Hartzmark's results imply that
} 


\section{DETERMINANTS OF TRADING PERFORMANCE, page 4}

This paper undertakes transaction-based tests in a very different arena--the international forward market for petroleum. The microdata we use have two important advantages for testing hypotheses about winners and losers in financial markets. First, as noted above, our information pertains to each individual transaction, rather than just end-of-day position data, all that has been available to previous researchers. Thus we are able to examine intraday trading. Second, the data indicate the type of companies involved in each transaction. These types (discussed further below) conform more closely to intuitive notions of speculators and hedgers than the arbitrary CFTC dichotomies of 1 arge vs. small and commercial vs. non-commercial positions upon which previous studies have been forced to rely. ${ }^{7}$

The petroleum forward market is organised quite differently from a futures market. A11 trading is bilateral; there is no clearinghouse, no open outcry, no centralised exchange. ${ }^{8}$ Only at the end of the trading day is information on deals negotiated during the day widely disseminated. During the day, traders must rely on their contacts for information on the transactions consummated. ${ }^{9}$ We take

sma 11 participants made significant losses in these markets.

7 Moreover, our types are defined by firms' long-run position in the industry, and not by their trading behaviour in a particular month. Of course. firms that produce and/or consume a good often engage in speculation as well. While it is impossible to be certain when a company that produces or consumes a good is hedging or speculating without knowing its future comitments in the cash (physicals) market at the time, such firms differ fundamentally from those that neither produce nor consume the good; the latter can profit only by on average selling relatively high and/or buying relatively low.

\footnotetext{
${ }^{8}$ Transactions are consumated via teiephone and telex; the terms are not public knowledge. All the data on this market are obtained by survey by firms that specialise in information collection and dissemination: one of these firms. Petroleum Arqus, maintains the historical microdatabase used in this study. Detailed information on the market can be found in Mabro et al (1986). Sas (1987a,b), and Weiner (1989).

${ }^{9}$ Subscribers to the services of the survey companies in this market receive an electronic report at the end of each trading day that includes individual transactions consumated that day. During the day, periodic price "assessments," in the form of bid/ask quotes, are sent out by the various survey companies, but these quotes are not necessarily based on actual transactions.
} 
advantage of the timing of information dissemination in this market to identify intraday performance with asymmetric information, and interday performance with the risk premia associated with normal backwardation.

The decentralised nature of this market allows us to isolate the role of asymmetric information as a determinant of trader performance. Unlike futures markets, price and quantity data here are not instantaneously available to market participants. Thus, to the extent that models of asymmetric information are relevant in understanding financial markets, they ought to receive empirical support here.

This setting should also be better suited than a futures market for testing the prediction of the normal-backwardation model regarding risk premia. ${ }^{10}$ As discussed below, entry into this forward market is far more costly than in futures markets. Individual investors cannot participate in the forward market, unless they are willing to participate in the physicals market as well.

Thus risk premia need not be competed away by an infinitely elastic supply of speculators. Failure to detect evidence of risk premia here would constitute stronger evidence against normal backwardation than it would in a futures market, where entry is relatively easy. This is important because the absence of free entry into speculation implies that the risk premia predicted by the theory of normal backwardation need not be driven to zero. ${ }^{11}$ Thus if normal backwardation

\footnotetext{
${ }^{10}$ The substantial price fluctuations in the underlying comodity, crude oil, should also serve to make this market a good laboratory for empirical research on risk premia.

${ }^{1}$ See the discussion above and Hirshleifer (1988).
} 
drives results in commodity markets, it should be more easily detectable here than in futures markets, where entry by small-scale speculators is relatively easy.

The remainder of the paper is organised as follows. Section II discusses market institutions and the database. The methodology for estimation of traders' gains and losses is presented in Section III. Empirical results are reported in Sections IV and $V$ for the interday accounts, and Section VI for the intraday accounts. Section VII offers some conclusions.

\section{The Brent Forward Market: Organisation and Data}

The commodity traded is Brent Blend crude 011 , a type of crude oil produced in the North Sea, which is one of the largest oil-producing areas in the world. The "Brent market" combines aspects of forward and futures contracting. As regards the former, all transactions are entered into bilaterally (in the absence of an exchange or clearinghouse), no margins are put up, and entering into an agreement requires the ability to take or make delivery should that be necessary (i.e., entering into an offsetting contract does not confer the right to automatic cash settlement). Contracts are governed by U.K. commercial 1 aw, but are denominated in U.S. dollars, the currency for virtually all international trade in crude oil.

Despite these characteristics of forward markets, the Brent market is primarily one of financial transactions--a feature usually associated with futures trading. Although no automatic right to financial settlement exists, over $90 \%$ of all contracts are settled financially, rather than through delivery. ${ }^{12}$ Contracts are

\footnotetext{
${ }^{12}$ Financial sett lement before contract maturity is referred to in this market as "booking out." In the absence of a clearinghouse, trading is not anonymous, so it necessary to keep track of the parties that have made commitments for future purchase and delivery.
} 


\section{DETERMINANTS OF TRADING PERFORMANCE, page 7}

standardised, as in a futures market, with all contract terms, save price, preestablished. ${ }^{13}$ In addition, formal futures trading of Brent contracts was successfully introduced by the International Petroleum Exchange in July 1988. ${ }^{14}$

Each record in the database represents a transaction, containing the date, contract maturity, type of buyer, type of seller, and price. As part of the agreement between the survey company and the respondents, individual trader records are not disclosed, but rather aggregated by type. Thus we will be unable to detect heterogeneity of trader performance within a given type. ${ }^{15}$ Table 1 summarises the trader types, and indicates their relative size in terms of numbers of reported transactions.

\footnotetext{
${ }^{13}$ Contract size is standardised at 500,000 barre is $(600,000$ barrels from 1985 through July 1988), roughly one tanker cargo, and delivery point at Sullom Voe, the Shet land Is lands. Forward contracts in this market have the same maturity structure as futures contracts; maturity is for a given month in the future (not for a given number of days in the future, as in the forward market for foreign exchange), and ranges from zero (spot transactions) to 5-6 months, with the bulk of trading for 1-3 months forward. There are no price-move or position limits.
}

${ }^{14}$ Crude oil futures trading has been active since its reintroduction by the New York Mercantile Exchange (NYMEX) in early 1983, and covers the period of our database. July 1983 through the end of 1989. In volume terms, the Brent forward market was about $15 \%$ of the size of the futures market during this period. The type of crude oil traded on the AYMEX is known as West Texas Intermediate (WTI). Crude oil is not a homogeneous commodity, and the many types of crude oil are imperfect substitutes, varying in how much gasoline, fuel oil, and other petroleum products they yield when refined. Price movements are imperfectly correlated across crude oi 1 types, in part because demand shocks (e.g., weather, coal strikes, air travel demand) tend to be specific to refined petroleum products.

${ }^{15}$ Two questions of data reliability arise when using survey information: 1) sample representativeness, and 2) respondents' incentives to reply truthfully. Neither is likely to be a serious problem here. The market is small enough, and reputation important enough, that whom to survey is not an issue. The survey is carried out every business day, and tries to reach all buyers and sellers in the market, rather than a sample of them. Only transactions verified by both buyer and seller are registered. A check of the effectiveness of the procedure reported in Mabro et a) (1986) est imated that the survey succeeded in registering roughly two-thirds of all transactions. The quality of the data is sufficiently high that the prices reported are very widely used in the petroleum industry as a basis for price-setting in long-term sales contracts for other types of crude oil (Petroleum Intelligence Week ly 1989). Trader reluctance to admit to having made a very good or a very poor bargain could bias our tests regarding "search account," profitability (described below) toward the null. 
TABLE 1: TRADER TYPES, CHARACTERISTICS, AND NUMBER OF TRANSACTIONS

Code Company Type Sales Purchases Description (example)

Companies with upstream or downstream capacity

I integrated $\quad 2900 \quad 3171$ upstream and downstream capacity (Amoco)

M major

59845634 very large integrated firms, operate the market (She11)

$N \quad$ national

157

185

state-owned enterprise, which would otherwise fall under $I, P, R$

p

producer

483

389

upstream capacity only (Hamilton)

$\mathbf{R}$

refiner

981

1152 downstream capacity only (AShland)

\section{Companies with neither upstream nor downstream capacity}

S sogo shosha

$\mathrm{T}$

U

W

Wa11 Street
3731

10264

3039

4637
3225

10578

3150

4692 companies that could not be classified by the survey

Japanese general trading companies (Mitsui)

other than S (Marc Rich)

U.S. investment banks (Dreyfus)

Note: Total number of transactions (equals sales equals purchases) is 32176 . The statistical work below excludes transactions between companies within the same category and swaps. The categories are mutually exclusive and collectively exhaustive. A list of companies by category is given in Petroleum Arqus (1987). 


\section{The Trading Accounts}

We construct two different accounts for each type of company, based on these individual transactions, in order to test for differential performance, and to determine the source of any performance differentials found. In-addition, we conduct non-parametric tests of forecasting ability developed by Merton (1981) and Henriksson and Merton (1981).

We first construct an account that measures interday performance, which we term the holding account. The holding account captures the profits that traders make on a given day on their open positions, based on price movements for the relevant contracts, and parallels the accounts constructed by earlier researchers in not relying on individual-transaction data. ${ }^{16}$

The normal backwardation hypothesis predicts holding-account profits for speculators and losses for hedgers, given the non-marketable risks combined with transactions costs associated with participating in the market discussed above. In contrast, the asymmetric-information theory would predict neither gains nor losses for any trader-type on the holding account, given the pattern of information dissemination in this market (see text and footnote 9 above), provided that traders had similar access to information about events other than the terms of deals consummated privately in this market.

Next we construct an account that measures intraday performance, which we term the search account. The search account captures traders ability to make (or to

\footnotetext{
${ }^{16}$ Our holding-account calculations are thus subject to the same limitations as the previous literature in the area of determining trader profitability in financial markets--profits and losses on positions held for less than one trading day will not register.
} 


\section{DETERMINANTS OF TRADING PERFORMANCE, page 10}

time) "good deals," measured as the amount above the daily mean (for the relevant contract maturity) a seller obtained, or the amount below the daily mean a buyer paid on each transaction. Again given the pattern of information dissemination in this market, the asymmetric-information theory would predict that traders with superior information would register gains on the search account.

\section{A. Holding Account}

Our method of construction is the same as previous authors', except for the prices that we use as the basis for posting gains and losses. In the absence of an exchange, there is no closing price for each forward contract. The choices available to us to proxy for the unobserved closing forward prices are 1) the closing prices for the corresponding futures contracts on the New York Mercantile Exchange; 2) the closing spot price; and 3) the average of the forward prices for each maturity.

The calculations reported below use the closing futures prices. ${ }^{17}$ Use of futures prices introduces noise into the estimation of traders' performance because of the imperfect correlation between prices of the types of crude $0 i 1$ traded on the forward and futures markets. ${ }^{18}$

\footnotetext{
17 In addition, the accounts were constructed using end-of-day spot prices, which effectively assumes away basis risk between spot and forward contracts. The last measure, the average of forward prices for each maturity, is not ut $i$ lised because these prices reflect the ability of the transacting parties to seek out favorable terms of trade in a market without centralised trading. This aspect of trading performance is discussed further below.

18 Although the two types of crude oil are quite similar, their prices do not move in lock-step together, due to transport costs in combination with local supply and demand effects (see footnote 14 above), and to differences in the timing of price reporting. The correlation between daily returns (measured in the usual manner as the logarithm of price changes) on the nearby NYMEX futures contract and the assessment (see footnote 9 above) for the nearby Brent forward contract over the period 1988-1991 was 0.745 . Crude oil futures trading on the NYMEX halts at 3:10 PM Eastern time. Since forward trading is informal. it could in principle take place around the clock. In practice, the westernmost oil trading center is Houston, and the end-of-day survey reports are issued at 5 PM
} 
Gains and losses calculated using closing futures prices were then cumulated over time to produce figures comparable to previous studies. The holding account measures profits associated with open positions at the end of each trading day. The account reflects, inter alia, market participants' ability to forecast price changes from one day to the next, given the information available to them. In equation form, the holding account for the $j^{\text {th }}$ trader-type on day $t, H_{j t}$, is:

$$
H_{j t}=\sum_{m}\left(p_{m t}-p_{m, t-1}\right) Q_{j m, t-1}
$$

where $m$ is contract maturity, $p$ is the price for a contract of maturity $m$, and $Q$ is the trader-type's open interest in contracts of maturity $m$ at the close of the preceding business day. ${ }^{19}$ Short positions are characterised by $Q<0$, so that traders who are short make money on the holding account when prices fall. of course, the sum across traders of profits is zero each day $\left(\sum_{j} H_{j t}=0\right.$ for all $\left.t\right)$.

\section{B. Tests of Forecasting Ability}

The holding account can record gains or losses that are statistically significant, even if a trader-type lacks forecasting ability. If futures prices rise (respectively, fall) over a given period, then traders who tend to be long for commercial reasons, e.g. refiners (respectively, short, e.g. producers), wi1l post significant gains, even in the absence of forecasting ability, as long as price changes are not completely anticipated. ${ }^{20}$

\footnotetext{
Houston time ( 6 PM Eastern time; Petroleum Arqus, communication). Exchange-rate movements are not an issue, since as noted above, both contracts are denominated in U.S. dollars.

19 When spot prices are used to construct the accounts, the right-hand-side of (1) reduces to the spot price change multiplied by the trader-type's net open position across all contract maturities.

20 Over the entire period the spot price declined substantially, from roughly $\$ 30$ to roughly $\$ 20$ per barrel.
} 
The difference between posting holding-account gains and exhibiting forecasting ability corresponds to the difference between the unconditional probability of being on the "right side of the market" (long when prices are rising, short when they are falling) and conditional probability of being on the right side of the market, given that prices are rising or falling.

We adapt methods for assessing market-timing performance developed by Merton (1981), Henriksson and Merton (1981), and Cumby and Modest (1987), and applied to futures markets by Chang (1985) and Hartzmark (1991). ${ }^{21}$ The tests that HenrikssonMerton (hereafter, $H-M$ ) develop are nonparametric, based on observing both predicted and actual changes in the variable being forecast. In the case of the forward market, we assume that traders' predictions are indicated by their net positions. In the absence of hedging, traders should hold long positions when they expect prices to rise, and short positions when they expect prices to fall.

The H-M test consists of summing the conditional probabilities of a correct position, given a price decrease, estimated as $N_{11} / N_{.1}$ in the contingency table below, and a price increase, estimated as $\mathrm{N}_{22} / \mathrm{N}_{.2}$. H-M demonstrate that the random variables in the contingency tables have hypergeometric distributions, with parameters $N, N_{1}$, and $N_{.1}$, which enables statistical inference.

\begin{tabular}{llllll} 
& \multicolumn{5}{c}{ PRICE CHANGE } \\
TRADER & down & up & total \\
POSITION & short & $N_{11}$ & $N_{12}$ & $N_{1 .}$ & $N_{1 j}=\#$ of observations \\
& long & $N_{21}$ & $N_{22}$ & $N_{2 .}$ & in cell i,j \\
& total & $N_{11}$ & $N_{.2}$ & $N$ &
\end{tabular}

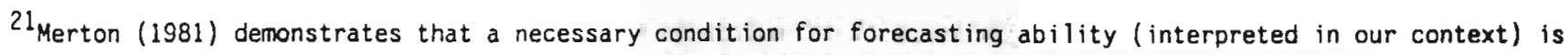
that the conditional probabilities of being on the right side of the market, given a price increase and a price decrease respectively, must sum to more than one. A producer, e.g., whose position is always short, is on the right side of the market with probability one when prices decline, but on the right side with probability zero when they $r$ ise, and thus would exhibit no forecasting ability. See references for further details.
} 
Cumby and Modest (hereafter, C-M, 1987) demonstrate two limitations of the H-M test. First, it is not very powerful against plausible alternatives; and second, it is valid only if returns are independent over time. ${ }^{22}$ C-M develop a regressionbased test under the assumption that the conditional expectation of the return depends linearly on the trader's forecast; the test consists of regressing the observed return (logarithm of the price change in this case) on a constant and an indicator variable, set equal to one for long positions, zero for short positions. If a trader-type has forecasting ability, the coefficient on this variable will be positive (i.e., long positions will be associated with price increases).

The $C-M$ approach is more powerful than the nonparametric tests, and does not rely on the independence assumption. Of course, regression-based tests have the drawback of assuming normality of forecast errors. As neither approach is a priori superior, we conducted both the $H-M$ nonparametric and $C-M$ regression-based tests.

\section{Search Account}

In addition to these measures of interday performance, a "search account" was constructed in attempt to measure companies" abilities to find "good deals" in a market with no open outcry, and non-instantaneous dissemination of information. In the absence of a normal-backwardation rationale for their presence in the market, traders that neither produce nor consume the commodity could survive by making trading profits through the ability to locate and take advantage of bargains faster than other types of companies. ${ }^{23}$

\footnotetext{
${ }^{22}$ If traders use technical anaiys is in taking positions (e.g., filter rules), then the independence assumption will be violated. For example, decisions based on troughs or peaks could lead to many sma 11 gains and a few big losses (or conversely), resulting in frequency-based tests, such as H-M's, giving mis leading results.

${ }^{23}$ The imperfect correlation between prices of Brent and WTI noted above implies that information-gathering in the forward market requires more than merely watching futures prices. Clearly, search-account gains and losses can result from intraday price fluctuation as well as differing abilities to find "good deals." Unfortunately, the
} 
For each forward-contract maturity, we calculate for each day an average price, based on all transactions in that maturity (unweighted; recall that transaction size is standardised). Each transaction that takes place above the average price results in a gain, equal to the difference from the average, being posted to the seller and a similar loss to the buyer, with analogous calculations for transactions taking place below the average price.

To construct each trader-type's search account each day, the gains and losses associated with individual transactions must be aggregated. Since these gains and losses are themselves estimated as the difference between the price associated with the individual transaction and the average price for all transactions of the relevant contract maturity, the standard error of estimate will differ between transactions of different contract maturities, so that constructing the search account via an unweighted average would be inappropriate.

In constructing the account, each gain or loss for the given trader-type was weighted by the inverse of the estimated variance of prices for the contract on which the gain or loss was incurred. In equation form, each trader-type's searchaccount performance on day $t$ was calculated as a weighted sum, $S_{j t}$ :

$$
S_{j t}=\sum w_{m} s_{m i j} /\left(\sum w_{m} / n_{j}\right), \quad w_{m}=1 / \sigma_{m}^{2}
$$

where the time subscript is suppressed for clarity on the RHS, $m$ indexes contract maturity, $i$ indexes transactions by the $j^{\text {th }}$ trader type in the $\mathrm{m}^{\text {th }}$ contract

\footnotetext{
exact time of each transaction is unavailable. Even when prices tend to rise or fall throughout the day, unless some types of companies systematically trade earlier in the day when prices are rising, or later in the day when prices are falling, the effects of intraday price variation will tend to cancel.
} 
maturity, and the summations are over $i$ and $m$. The $j^{\text {th }}$ trader's gain or loss associated with each of its transactions is $s_{m i j}=\left(P_{m i j}-\bar{P}_{m}\right) I_{m i j}$, where $P_{m i j}$ is the transaction price, $\bar{P}_{m}$ is the average price across all transactions of the relevant contract maturity and $I$ is an indicator variable, equal to one for sales and negative one for purchases. $W_{m}$ is the weight, $n_{j}$ the number of transactions by the trader-type for the day, and $\sigma_{\mathrm{m}}^{2}$ the variance of the estimated gain or loss on the transaction. ${ }^{24}$ The variance is estimated from all the transactions by all traders in the given contract maturity on day $t$.

The daily search account represents an estimate of a trader-type's ability to do better than the average of a 11 traders. To assess the statistical significance of the estimate, a standard error must be calculated:

$$
\operatorname{var} S_{j t}=\sum w_{m}^{2} \sigma_{m}^{2} /\left(\sum w_{m} / n_{j}\right)^{2}=\left[\sum\left(1 / n_{j}^{2} \sigma_{m}^{2}\right)\right]^{-1}
$$

where the variables and summation are as before, and the time subscript is again suppressed on the RHS. The same procedure serves to generate the search account for any time period. The daily search accounts are aggregated with weights as in (2), with the weights now being the daily variances that were calculated through (3).

\section{Holding Account: Results}

Table 2 presents the results of constructing the holding-accounts for each tradertype for the entire period. For each trader-type, the table provides total

\footnotetext{
${ }^{24}$ Thus the estimated gain or loss on each transaction is weighted by its corresponding element in the covariance matrix. See Lehman (1990).
} 
TABLE 2: HOLDING ACCOUNT

A. GAINS AND LOSSES BY TRADER TYPE

TOTAL

STD. ERROR

NET POSITION

$\begin{array}{rrrrrrrrr}I & M & N & P & R & S & T & U & W \\ -59079 & -121 & 2463 & 18957 & 9498 & 13761 & 149283 & 23696 & -158858 \\ 76536 & 134892 & 31049 & 35993 & 60279 & 69093 & 239342 & 86945 & 126521 \\ -3297 & -26731 & 1024 & -3020 & 2023 & 7860 & 12004 & 1777 & 8360\end{array}$

B. GAINS AND LOSSES BY POTENTIAL HEDGERS $\left(' I ',{ }^{\prime} M^{\prime},{ }^{\prime} N{ }^{\prime},{ }^{\prime} P{ }^{\prime},{ }^{\prime}{ }^{\prime}\right.$, and somet imes ' $W$ ')

TOTAL

STD. ERROR

NET POSITION

$$
\text { excluding ' } W \text { ' }
$$

$$
-27882
$$

173120

$-30001$ including ' $W$ '

$-186740$

227818

$-21641$

Note: $\quad I$ integrated $M$ major $N$ national $P$ producer $R$ refiner $S$ shosha $T$ trading co. $U$ unident. $W$ Hall St. Totals and standard errors in thousands of dollars, net position in number of contracts. Significance leveis (2-tailed test) a $-10 \%, b-5 \%$

profits (calculated as the sum of daily holding profits), and its standard error; negative signs indicate losses. Only the levels of returns are indicated; because no margin capital need be put up, there is no natural denominator for calculating rates of return. The table also indicates the size of each trader-type in terms of net open interest (i.e., the stock of contracts outstanding), with positive signs indicating long positions and negative signs, short positions. ${ }^{25}$

Table $2 \mathrm{~B}$ presents the holding account totals aggregated by whether trader-types are potential hedgers--i.e., possess production or consumption capacity. The

\footnotetext{
${ }^{25}$ Table $3 \mathrm{~A}$ be low provides an analogous indication of trader size in terms of total trading volume (i.e., flow of contracts signed).
} 
leftmost five columns of Table $2 \mathrm{~A}$ fall into this category; the remaining four columns represent trading companies--traders with no production or consumption to hedge--who are the speculators in this market. The table also presents figures with the Wall Street banks included in the hedger category, because this group sells hedging services to companies that engage in production or consumption of the physical commodity, often through tailored long-term commodity swaps.

Over the entire period, no trader-type posted a gain or loss that is significant at the $10 \%$ level, nor did the hedgers as a group, whether or not the Wall Street banks are included. Of course, the speculators (however defined) also broke even on the holding account, since their balances are just those of the hedgers with the signs reversed.

The holding accounts were also constructed for each trader-type for each six-month period from 1983:2 to 1989:2.26 The subperiod breakdowns are calculated because the market has evolved over time. Some subperiods have witnessed sharp price fluctuations, while others have been calm. ${ }^{27}$ The normal-backwardation hypothes is predicts that the insurance premium paid by hedgers to speculators for taking on risk will be greater in periods of higher volatility. Thus, hedgers should register larger holding-account losses during these periods.

\footnotetext{
${ }^{26}$ Periods start in January and July. No correction for seasonality was made; Dominguez (1991) examined returns on WTI crude oil futures contracts over this period, finding no evidence of seasonality in returns. The same result was obtained for WTI spot prices by Garbade (1991).

${ }^{27}$ Historical volatility levels have fluctuated: standard deviations of percentage daily price changes ranged from less than $10 \%$ to about $20 \%$ per year before 1986, rose dramatically to around $40 \%$ to over $100 \%$ per year in 1986 . then fell back to the 20 to $60 \%$ per year range in the late 1980 s. Although after the period of our sample, ana logous volatility figures published by the NYMEX for the Gulf $\mathrm{Cr}$ is is of 1990-91 exceed $100 \%$ per year.
} 
Of the 101 subperiod balances (13 subperiods for 8 trader-types, less 3 cases where a trader-type was inactive for a subperiod), only two were statistically significant at the 5\% (and three at the 10\%) level (two-tailed test), fewer than the number expected by chance. When the accounts were aggregated by whether trader-types are potential hedgers, not one of the 13 subperiod figures for hedger and speculator profits differed statistically from zero at the $10 \%$ significance leve1.28

Following Bessembinder (1992), we also constructed the holding account balances conditional on the potential hedgers' being net long and net short as a group. Whereas Bessembinder, relying on CFTC data, finds that futures contracts tend to have higher returns when hedgers are net short than net long, our conditional holding-account balances, like the unconditional balances reported above, do not differ from zero for any trader-type at conventional significance levels.

Bessembinder tests the portfolio theory against Hirshleifer's modern version of the normal backwardation approach by regressing futures returns on measures of 1) systematic risk, and 2) residual risk in the relevant futures market, interacted with a variable indicating when hedgers (as defined by the CFTC) are long or short. His finding of a relationship between returns and residual risk, interacted with hedging position, provides support for the latter.

We performed a modified version of Bessembinder's tests, taking advantage of our ability to distinguish conmercials' and noncommercials' transactions. The daily holding-account balances of the "potential hedgers" group (see Table 2B) were

\footnotetext{
28 Because the subperiod balances are all nul1, they are omitted here in the interests of space. Tables with these figures are available in the working paper version of this article (Phillips and Weiner 1991).
} 


\section{DETERMINANTS OF TRADING PERFORMANCE, page 19}

regressed against the estimated standard deviation of returns on futures contracts and an indicator variable for the sign of this group's net position:

$$
\sum_{j} H_{j t}=\alpha+\beta \sigma_{t}\left(1+\gamma I_{t}\right)+\epsilon_{t}
$$

where the summation is over the commercial trader types, $\sigma$ is the standard deviation of returns on futures contracts (estimated from historical data, and from implied volatility, backed out of options on NYMEX futures contracts), and I is the indicator variable $\left(I_{t}=-1\right.$ if net short on day $t, I$ if net long, 0 if zither). Consistent with our findings above, the estimated coefficients $\hat{\alpha}, \hat{\beta}$, and $\hat{\gamma}$ did not differ from zero at the $5 \%$ significance level. Estimation of (4) separately for each trader-type produced similarly insignificant results.

These tests differ from Bessembinder's in two important ways. First, we employ holding-account profits, rather than rates of return, as our dependent variable. Recall that for forward contracts, no capital is invested, so that rates of return are not meaningful. Our holding account measures, like Bessembinder's rates of return, will vary with futures prices. Second, $\sigma$ here is a measure of total, rather than residual risk. Given our findings of insignificant gains and losses above, we have not performed the extensive asset-pricing tests necessary to decompose $\sigma$ into the systematic and residual components necessary to test directly Hirshleifer's proposed form of hedging interaction with residual risk. ${ }^{29}$ Note that these modifications limit the comparability of these tests with Bessembinder's.

\footnotetext{
29 Moreover, earlier authors (e.g.. Mayshar 1981) have demonstrated total risk to be a determinant of an asset's risk premium in the presence of transactions costs.
} 


\section{v. Forecasting Ability: Results}

The H-M nonparametric tests are unable to detect forecasting ability among any of the nine trader-types at conventional significance levels; the smallest p-value is 0.39. Five of the nine types perform worse than a trader guessing randomly, al though the differences are not significant at conventional levels. ${ }^{30}$ An examination of the subperiod results reveals evidence of forecasting ability (i.e., the sum of the conditional probabilities exceeded one at the $10 \%$ significance level) in only three (out of 114) cases.

As a check on whether our results are due to low power of the nonparametric approach, we also performed the C-M regression-based tests described earlier. Changes in the futures price were regressed on a constant and a dummy variable that indicated whether the given trader was long or short on a given day. In only

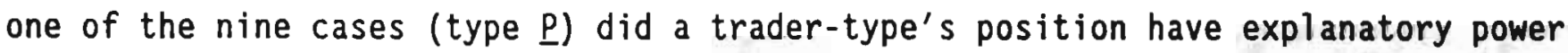
at the $10 \%$ level. This case had the "wrong" sign; prices tended to fall when producers were long. ${ }^{31}$ Thus the regression-based tests yield results consistent with the earlier conclusions of no interday forecasting ability.

\footnotetext{
${ }^{30}$ For space reasons, only an illustrative matrix (for type I) is shown here. Full results are presented in the appendix. The matrix indicates the number of days on which long or short positions were held, and the number of days on which the one-month futures price rose or fell. Also indicated are the sum of the conditional probabilities of being on the right side of the market, given that it has risen and fallen, respectively, and the probability that this sum differs from one. its expected value if positions were chosen randomily.

Trading Company FUTURES PRICE MOVEMENT

TRADER

POSITION

\begin{tabular}{lccl}
\multicolumn{5}{c}{ FUTURES PRICE } & MOVEMENT \\
& down & up & tota l \\
short & 294 & 310 & 604 \\
long & 434 & 528 & 960 \\
total & 728 & 836 & 1564
\end{tabular}

sum of conditional probabilities $=1.03 ; p$-value $=.39$

The calculations are not sensitive to which futures maturity is used, because although imperfectly correlated. futures prices of differing maturities nearly always move in the same direction. Days on which the futures price was unchanged are included under 'up'. Days on which the trader-type held no net position are not included in its matrix.
} 


\section{DETERMINANTS OF TRADING PERFORMANCE, page 21}

\section{Search Account: Results}

\section{A. Aggregate Performance}

Table $3 A$ presents the search accounts constructed for each trader-type for each six-month period from 1983:2 to 1989:2, as well as for the entire period. Examining the entire period first, it can be seen that of the four trader types that neither produce nor refine the commodity traded, only the shosha (labeled $s$ ) are estimated to have made a profit at the $95 \%$ confidence level, about $\$ 8.7$ million. Other trading companies (I) are estimated to have lost around $\$ 3.6$ million, significant at the $90 \%$ level. The Wall Street banks (WW) also lost about $\$ 3.6$ million, significant at the $95 \%$ level. Of the other groups, only the majors $(\underline{M})$, who run the market (and who are thus the most likely to have superior information), made a significant profit, around $\$ 4.2$ mi11ion. The unidentified group (U), comprising companies unlikely to be knowledgeable about the market, lost about $\$ 5.5$ million. Gains and losses by other types were not significant at the $90 \%$ lever.

The figures for the thirteen subperiods vary some, but are largely consistent with the aggregate results. The shosha made a profit every period (except 1983:2, when they had a minuscule nine transactions). Other trading companies lost in ten out of the thirteen periods. The Wall Street Banks lost money in all but two of the periods they were active (in one of the two, 1984:2, they had but 2 transactions), as did refiners. The unidentified group lost money every period.

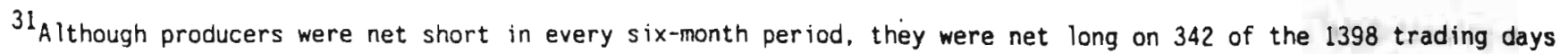
in which they heid a position.
} 
$1983: 2$

TOTAL

STD. ERROR

TRANSACTIONS

$1984: 1$

TOTAL

STD. ERROR

TRANSACTIONS

$1984: 2$

TOTAL

STD. ERROR

TRANSACTIONS

$1985: 1$

TOTAL

STD. ERROR

TRANSACTIONS

$1985: 2$

TOTAL

STD. ERROR

TRANSACTIONS

$1986: 1$

TOTAL

STD. ERROR

TRANSACTIONS

$\begin{array}{rrrrrrrrr}I & M & N & P & R & S & T & U & W \\ 47 & 258 & 20 & 43 & -76 & -34 & -105 & -168 & 0 \\ 128 & 200 & 48 & 122 & 134 & 76 & 254 & 112 & . \\ 54 & 109 & 1 & 30 & 32 & 9 & 150 & 39 & 0\end{array}$

$\begin{array}{rrrrrrrrr}I & M & N & P & R & S & T & U & W \\ 99 & 321 & -37 & -92 & -40 & 114 & -329 & -185 & 0 \\ 153 & 204 & 25 & 96 & 140 & 75 & 264 & 155 & \text { D } \\ 155 & 255 & 4 & 48 & 79 & 52 & 423 & 106 & 0\end{array}$

$\begin{array}{rrrrccrrr}I & M & N & P & R & S & T & U & W \\ -118 & 589^{\mathrm{a}} & -3595^{\mathrm{b}} & -194 & -221 & 155 & 135 & -678^{\mathrm{b}} & 8 \\ 283 & 342 & 703 & 225 & 277 & 169 & 405 & 263 & 71 \\ 289 & 503 & 5 & 114 & 163 & 172 & 753 & 277 & 2\end{array}$

$\begin{array}{rrrrrrrrr}\mathrm{I} & \mathrm{M} & \mathrm{N} & \mathrm{P} & \mathrm{R} & \mathrm{S} & \mathrm{T} & \mathrm{U} & W \\ 599 & 1186^{\mathrm{b}} & -86 & -65 & -256 & 101 & -542 & -1000^{\mathrm{b}} & -\mathbf{4 8} \\ 406 & 576 & 55 & 289 & 197 & 304 & 749 & 448 & 44 \\ 452 & 570 & 3 & 135 & 80 & 194 & 1045 & 400 & 7\end{array}$

1986:2

TOTAL

STD. ERROR

TRANSACTIONS

$\begin{array}{rrrrrrrrr}I & M & N & P & R & S & T & U & W \\ 161 & -1149^{\mathrm{b}} & -435 & -19 & -625^{\mathrm{a}} & 624 & 1611^{\mathrm{b}} & -858^{\mathrm{b}} & -39 \\ 434 & 517 & 615 & 199 & 360 & 406 & 711 & 433 & 84 \\ 486 & 786 & 1 & 131 & 181 & 416 & 1389 & 392 & 54\end{array}$

$\begin{array}{rrrrrrrrr}\mathrm{I} & \mathrm{M} & \mathrm{N} & \mathrm{P} & \mathrm{R} & \mathrm{S} & \mathrm{T} & \mathrm{U} & \text { W } \\ 340 & -328 & 315 & 87 & -424 & 1504^{\mathrm{b}} & -813 & -930 & -437 \\ 803 & 893 & 232 & 330 & 435 & 644 & 1051 & 714 & 456 \\ 397 & 578 & \mathrm{I} & 31 & 122 & 459 & 827 & 154 & 241\end{array}$

$\begin{array}{rrrrrrrrr}I & M & N & P & R & S & T & U & W \\ -124 & -425 & -9 & 58 & -89 & 2007^{b} & -440 & -359 & -518 \\ 446 & 672 & 13 & 138 & 550 & 783 & 996 & 520 & 736 \\ 341 & 762 & 1 & 31 & 140 & 666 & 1031 & 166 & 596\end{array}$

Note: I integrated $M$ major $N$ national $P$ producer $R$ refiner $S$ shosha $T$ trading co. $U$ unident. $W$ Wall St. Totals and standard errors in thousands of dollars. transactions in number of contracts. Each trade is counted twice, once for the buyer and once for the seller. Not counted are swaps and trades wherein the two parties are of the same trader-type. Significance levels (2-tailed test): $a-10 \%, b-5 \%$. 
Table 3A: SEARCH ACCOUNT-(continued)

GAINS AND LOSSES BY TRADER TYPE

$1987: 1$

TOTAL

STD. ERROR

TRANSACTIONS

$\begin{array}{rcccccccc}\mathrm{I} & \mathrm{M} & \mathrm{N} & \mathrm{P} & \mathrm{R} & \mathrm{S} & \mathrm{T} & \mathrm{U} & \mathrm{W} \\ 124 & 2078^{\mathrm{b}} & 0 & -11 & 108 & 1033^{\mathrm{b}} & -2251^{\mathrm{b}} & -419 & -839^{\mathrm{a}} \\ 369 & 540 & . & 98 & 239 & 461 & 610 & 317 & 458 \\ 356 & 843 & 0 & 48 & 177 & 615 & 999 & 277 & 607\end{array}$

$1987: 2$

TOTAL

STD. ERROR

TRANSACTIONS

$\begin{array}{crrrrrrrr}I & M & N & P & R & S & T & U & N \\ -956^{\mathrm{a}} & 353 & 20 & 498^{\mathrm{a}} & -240 & 3448^{\mathrm{b}} & -176 & -322 & -1428^{\mathrm{b}} \\ 564 & 762 & 24 & 268 & 283 & 746 & 902 & 439 & 682 \\ 493 & 1053 & 1 & 79 & 173 & 783 & 1373 & 384 & 1019\end{array}$

1988:1

TOTAL.

STD. ERROR

$\begin{array}{rrr}1 & M & N \\ 112 & 1021 & -30\end{array}$

$\begin{array}{rr}P & R\end{array}$

$\begin{array}{crrr}S & T & U & W \\ 1137^{\mathrm{b}} & -549 & -426 & -922 \\ 513 & 743 & 487 & 684 \\ 485 & 1031 & 310 & 1070\end{array}$

TRANSACTIONS

$634 \quad 666$

$\begin{array}{rrr}-30 & -37 & -202 \\ 76 & 151 & 230\end{array}$

$36 \quad 50 \quad 156$

1988:2

TOTAL

STD. ERROR

TRANSACTIONS

$\begin{array}{rrrrrrrrr}\mathrm{I} & \mathrm{M} & \mathrm{N} & \mathrm{P} & \mathrm{R} & \mathrm{S} & \mathrm{T} & \mathrm{U} & W \\ 207 & -248 & 351^{\mathrm{a}} & -275 & -303 & 59 & 886 & -591 & -206 \\ 382 & 565 & 210 & 214 & 489 & 474 & 897 & 471 & 732 \\ 423 & 753 & 48 & 18 & 154 & 229 & 795 & 267 & 827\end{array}$

1989:1

TOTAL

STD. ERROR

TRANSACTIONS

$\begin{array}{rrrrrrrrr}I & M & N & P & R & S & T & U & W \\ 79 & -229 & 63 & -72 & -96 & 21 & -114 & -228 & 698^{a} \\ 261 & 246 & 197 & 110 & 176 & 141 & 320 & 329 & 419 \\ 204 & 268 & 97 & 9 & 70 & 58 & 324 & 176 & 392\end{array}$

1989:2

TOTAL

STD. ERROR

TRANSACTIONS

$\begin{array}{rrrrrrrrr}\mathrm{I} & \mathrm{M} & \mathrm{N} & \mathrm{P} & \mathrm{R} & \mathrm{S} & \mathrm{T} & \mathrm{U} & W \\ -33 & 108 & 220^{\mathrm{a}} & 30 & 134^{\mathrm{a}} & 77 & -441^{\mathrm{a}} & -65 & -72 \\ 196 & 190 & 129 & 50 & 81 & 105 & 243 & 177 & 221 \\ 215 & 233 & 71 & 15 & 41 & 63 & 277 & 171 & 328\end{array}$

ENTIRE PERIOD

TOTAL

$\begin{array}{rrrrrrrrr}\mathrm{I} & \mathrm{M} & \mathrm{N} & \mathrm{P} & \mathrm{R} & \mathrm{S} & \mathrm{T} & \mathrm{U} & W \\ 822 & 4218^{\mathrm{b}} & 291 & -180 & -1402 & 8663^{\mathrm{b}} & -3570^{\mathrm{a}} & -5455^{\mathrm{b}} & -3575^{\mathrm{b}} \\ 1312 & 1722 & 290 & 548 & 881 & 1420 & 2133 & 1185 & 1474 \\ 4310 & 7728 & 269 & 739 & 1568 & 4201 & 10417 & 3119 & 5143\end{array}$

STD. ERROR 431

Note: I integrated $M$ major $N$ nationa 1 p producer $R$ refiner $S$ shosha $T$ trading co. $U$ unident. W Wall St. Totals and standard errors in thousands of dollars, net position in number of contracts. Each trade is counted twice, once for the buyer and once for the seller. Not counted are swaps and trades where in the two parties are of the same trader-type. Significance levels (2-tailed test): a - 10\%, b-5\%. 
Note also that the magnitude of the gains and losses diminishes toward the end of the period. As noted above, futures trading in Brent crude oil was successfully introduced in the second half of 1988. With instantaneous dissemination of information available, the degree of information asymmetry among market particiants should have decreased, leading to smaller magnitudes on the search account. This result too is consistent with information-based views of trader performance.

When the search account figures are aggregated into hedger and speculator categories (as in Table 2 above), the majors' profits are more than large enough to offset the losses of the other hedgers. This yields a profit over the entire period for the group of $\$ 4.5$ million (and hence, a loss for the speculators) that is significant at conventional levels (standard error $\$ 2.2$ million) when type $H$ is excluded. Not surprisingly, aggregation across trader-types with quite disparate performance tends to reduce the extent to which results differ significantly from zero. Including type $W$ reduces the hedgers' search account gain to $\$ 1.0$ million, with standard error $\$ 2.2$ million.

B. Performance Breakdown by Trading Partner

Disaggregation of the each trader-type's search-account by trading partner allows us to address the question of whether those types that did well (respectively, poorly) at making deals registered their gains (respectively, losses) in transactions with all other trader-types, or primarily with those who fared poorly (respectively, we11).

Table 3B presents an illustrative performance matrix, disaggregated by trading partner, for those trader types that registered significant gains or losses over the entire period in Table $3 A(\underline{M}, \underline{S}, \underline{I}, \underline{U}$, and $\underline{W})$. When the trader types that did 
Table 3B: SEARCH ACCOUNT

GAINS AND LOSSES BY TRADER TYPE, DISAGGREGATED BY TRADING PARTNER

Entire Period

\begin{tabular}{|c|c|c|c|c|c|c|}
\hline & & $M$ & $S$ & $T$ & $\mathbf{U}$ & $W$ \\
\hline$M$ & $\begin{array}{r}\text { total } \\
\text { std. err. }\end{array}$ & - & & & & \\
\hline 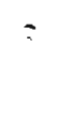 & $\begin{array}{r}\text { tota } 1 \\
\text { std. err. }\end{array}$ & $\begin{array}{l}796 \\
650\end{array}$ & -- & & & \\
\hline$T$ & $\begin{array}{r}\text { total } \\
\text { std. err. }\end{array}$ & $\begin{array}{r}-1630 \\
1137\end{array}$ & $\begin{array}{c}-3350^{b} \\
917\end{array}$ & - & & \\
\hline$U$ & $\begin{array}{r}\text { total } \\
\text { std. err. }\end{array}$ & $\begin{array}{c}-2033^{b} \\
558\end{array}$ & $\begin{array}{c}-1195^{b} \\
374\end{array}$ & $\begin{array}{c}-1655^{b} \\
718\end{array}$ & -- & \\
\hline$W$ & $\begin{array}{l}\text { total } \\
\text { std. err. }\end{array}$ & $\begin{array}{l}354 \\
736\end{array}$ & $\begin{array}{c}-2255^{b} \\
571\end{array}$ & $\begin{array}{r}-667 \\
835\end{array}$ & $\begin{array}{r}-547 \\
429\end{array}$ & -- \\
\hline
\end{tabular}

Note: Totals and standard errors in thousands of dollars.

Sign convention: + indicates that the row made money off the column: - indicates the converse.

Significance levels (2-tailed test): a - 10\%, b - 5\% 


\section{DETERMINANTS OF TRADING PERFORMANCE, page 26}

not make significant gains or losses over the entire period are included (not shown here, available upon request), the results suggest that the winners in Table $3 A$ gained at the expense of the types that lost overall, rather than at the expense of al1 other groups.

For example, the shosha $(\underline{S})$, which performed the best, gained at the expense of seven of the other eight groups, posting a(n insignificant) loss only in their deals with producers. The shosha's significant gains were all at the expense of the other trading companies, types $I, \underline{U}$, and $\underline{W}$, which all fared poorly. The majors made their only significant gains at the expense of types $I$ and $\underline{U}$. Among the losers, the unidentified group ( $\underline{U})$ posted losses in its deals with all other groups but $W$, and the Wall Street banks (W) lost to all groups but $I$ and $\underline{P}$. Neither $\underline{U}$ nor $\underline{W}$ made significant gains at the expense of any other group.

The fact that the types that profited overall ( $\underline{M}$ and $\underline{S}$ ) did not incur significant losses to any of the other types, and the types that lost overall (I, $\underline{U}$, and $\underline{W})$ did not succeed at the expense of any of the other groups suggests the presence of an informational ordering. The groups with superior information gained at the expense of those with inferior information. In contrast, had it been the case that type $A$ gained at the expense of type $B$, which gained at the expense of type $C$, which in turn gained at the expense of type $A$, then arguments based on informational asymmetry would have been difficult to make.

An alternative explanation to asymmetric information for the disparate performance of the various trader-types is default risk. Perhaps the finding that speculator groups tend to do badly reflects a "default risk premium" associated with their creditworthiness. Entry into speculation in this market requires far less capital than entry into refining or undersea $0 i 1$ production. In the absence of a 
clearinghouse and the daily posting of margins to protect against defautt risk ("marking-to-market"), a large enough paper loss might leave lightly capitalised traders unable to fulfill their contractual obligations.

To investigate the possibility that our results arise from differential default risk, rather than asymmetric information, we examined incentives to default among lightly-capitalised trading companies, assigning all the transactions among hedgers to a "low-risk" group, and transactions between hedgers and speculators, to a "high-risk" group. For each transaction, we computed a measure of the incentive to default by assuming that traders could walk away from their contractual obligations costlessly. Costless default can be modeled as an implicit option in the forward contract. The incentive to default on each contract was estimated by using standard techniques to value an implicit put option for the seller and an implicit call option for the buyer when the contract was signed. ${ }^{32}$

When the values of the default option are compared between groups for each contract maturity in each subperiod, the differences are almost all economically and statistically insignificant. ${ }^{33}$ Given that these option values overestimate the incentive to default, by assuming that default is costless, we conclude that differences in default-risk premia cannot explain our search-account results.

\footnotetext{
${ }^{32}$ The Black-Scholes option valuation formula was used, with price volatility estimated from historical futures prices (supplemented by implicit volatility estimates from crude oil options prices from the start of options trading in 1986). Since we are comparing values between groups, any errors arising from the appropriateness of the Black-Scholes formula's assumptions should be at most second order. See Phillips and Weiner (1990) for further discussion.

${ }^{33}$ of the 40 differences ( 13 subperiods, each with an average of about 3 contract maturities with enough observations to compute standard errors) between the "low risk" and "high risk" groups in mean default-option value, only 3 were significant at the $5 \%$ level (one-tailed test), and one of these had the wrong sign. Threefourths of these differences were less than $\$ 0.01$ per barrel; the maximum difference over all subperiods and contract maturities was only $\$ 0.14$ per barrel. in comparison with a typical contract price of $\$ 20$ per barrel.
} 


\section{Conclusion}

Our finding of no significant profits or losses on the holding (interday) account does not support the theory of normal backwardation, because hedgers do not pay for, and speculators do not receive, fees for insurance provision. Such a result is stronger here than in a futures market, because entry into speculation in the Brent forward market is limited by the large transaction size and absence of a clearinghouse and right to close out positions automatically through offsetting transactions, implying the necessity to be able to operate in the cash market. If the risk premia predicted by normal-backwardation are not present here, they are even less likely to be found in a futures market, where ease of entry into speculation tends to reduce or eliminate speculators' returns to bearing risk.

The absence of significant profits, and the lack of forecasting ability, however, are also inconsistent with views based on asymmetric information from one day to the next. These results differ from those of previous researchers, who have found support for the normal-backwardation theory) in one case (Chang 1985), and that hedgers actually made money on what we term the holding account in another (Hartzmark 1987).34

In analysing performance based on individual transactions, we find evidence supportive of the asymmetric-information view of forward and futures markets. The major oil companies posted significant profits. This finding is not entirely surprising, as the majors operate the Brent delivery system, which implies deciding on how many cargoes will be lifted each month, as well as when during the

\footnotetext{
${ }^{34}$ An alternative explanation for our results is that both asymetric information and normal backwardation hold in this market, and just happen to cancel, explaining the insignificant results obtained above on the holding account. We thank an anonymous referee for pointing out this possibility.
} 
month each producing company's $0 i 1$ will be lifted. ${ }^{35}$ The majors also produce the bulk of the oil in the Brent fields, as suggested by the fact that they hold most of the net short position, as can be seen in Table $2 A$. If any group is 1 ikely to have access to more information than the others, it is the majors. It appears, however, that the value of this information does not extend beyond the end of the trading day. As noted above, this result is consistent with the time pattern of information dissemination in this market--deals made during the day are widely reported only at day's end.

We can gain insight into trader heterogeneity by comparing the performance of our four types of trading companies. ${ }^{36}$ of the four speculator groups, three posted significant losses; only the Japanese trading houses posted the gains predicted by the view that the trading companies' advantage lies in gathering and interpreting information rapidly. Of the losers, the easiest to explain is the "unidentified" group of traders, who are the most likely to have inferior information. The very fact of being assigned to this category indicates that a company is not in the market often enough to be known to the market surveyors. That this group lost money every period is also supportive of an intraday asymmetric-information view.

\footnotetext{
${ }^{35}$ The oil is in common pools under the North Sea, with property rights determined by the fraction of the field owned by each producer. Delivery takes place through lifting the oil from undersea pipelines to the loading platform, and then to the tanker. Lifting schedules are decided upon a month in advance. Accounts in the trade press suggest that the supply is price-inelastic, but fluctuates from month to month for a variety of reasons (primarily weather- and maintenance-related) not directly related to oil prices. For an example of how decisions regarding the market can affect prices, see the trade paper Week ly Petroleum Arqus (1993, p.12): "The announcement of a 55 cargo July Brent programe. 17 cargoes more than in June and on the high end of market expectattons, exacerbated the already bearish mood."

${ }^{36}$ The shosha historically have handled a large fraction of Japanese exports and imports. The expertise of the Wall Street banks, which have included Bear Stearns, Chase Manhattan. Drexel, J. Aron (Goldman Sachs), and Morgan Stanley, is in financial deals. Other trading companies arose primarily from within the oil industry, from the transport and trading divisions of the majors and large integrated companies. The unidentified category, comprising occasional market participants. also consists of trading companies, as it is unlikely to include firms with production or refining capacity.
} 
Explaining the performance of the Wall street banks is more difficult. It is possible that the fees they collected from the clients on whose behalf they trade were more than enough to offset the $\$ 3.6$ million they lost on the search account. The diversity of traders' experiences suggests that lumping them together as "speculators," or "non-commercials," as in the CFTC reporting system, is not usefur for the purpose of economic analysis, and likely to obscure more than it reveals regarding trading performance. Our results also suggest that differential default risk does not account for the diversity of trader performance. Explaining this diversity remains an unanswered question, and a subject for future investigation. 


\section{References :}

Bessembinder, Hendrik (1992). 'Systematic risk, hedging pressure, and risk premia in futures markets,' Review of Financial Studies 5, \#4, pp. 637-667.

Cumby, Robert E., and David M. Modest (1987). 'Testing for market timing ability: a framework for forecast evaluation.' Journal of Financial Economics 19 (September), pp. 169-189.

Dominguez, Kathryn M. (1991). 'Forecasting strategies in oil financial markets.' In oil Markets in a Turbulent Era, by Kathryn M. Dominguez, et al., Cambridge: President and Fellows of Harvard College.

Dusak, Katherine (1973). 'Futures trading and investor returns: an investigation of commodity market risk premiums,' Journal of Political Economy 81 (November/ December), pp. 1387-1406.

'Formula oil pricing--nothing succeeds like success' (1989). Petroleum Intelligence Weekly 28, \#1 (January 2), pp. 3-4.

Garbade, Kenneth D. (1991). 'Characteristics of fluctuations in the prices of crude $0 i 1$ and its refined fuels,' Bankers Trust Topics in Money and Securities Markets \#72, January.

Grossman, Sanford J., and Joseph E. Stiglitz (1980). 'On the impossibility of informationally efficient markets,' American Economic Review 70 (June), pp. 393408.

Hartzmark, Michael L. (1987). 'Returns to individual traders of futures: aggregate results.' Journal of Political Economy 95 (December), pp. 1292-1306.

Hartzmark, Michael L. (1991). 'Luck versus forecast ability: determinants of trader performance in futures markets,' Journal of Business 64 (January), pp. 4974.

Henriksson, Roy D., and Robert C. Merton (1981). 'On market timing and investment performance, II: statistical procedures for evaluating forecasting skills.' Journal of Business 55 (October), pp. 513-533. 
Hicks, John R. Value and Capital, 2nd ed. Oxford:-0xford University Press.

Hirshleifer, David (1988). 'Residual risk, trading costs, and commodity futures risk premia.' Review of Financial Studies 1 (Summer), pp. 173-193.

Houthakker, Hendrik S. (1957). 'Can speculators forecast prices?' Review of Economics and Statistics 39 (May), pp. 143-151.

Kawai, Masahiro (1983). 'Spot and futures prices of nonstorable commodities under rational expectations.' Quarterly Journal of Economics 48 (May), pp. 235-254.

Keynes, John Maynard (1930). A Treatise on Money, Volume 2. London: MacMillan and Co.

Lehman, Bruce N. (1990). 'Residual risk revisited.' Journal of Econometrics 45 (Juty-August), pp. 71-97.

Mabro, Robert, et a1 (1986). The Market for North Sea Crude 0i1. 0xford: 0xford University Press.

Mayshar, J. (1981). 'Transaction Costs and the Pricing of Assets." Journal of Finance 36, pp. 583-597.

Merton, Robert C. (1981) 'On market timing and investment performance, I: an equilibrium theory of value for market forecasts.' Journal of Business 55 (July), pp. 363-406.

Petroleum Arqus (1987). 'Crude oil deals database,' mimeographed.

Phillips, Gordon M., and Robert J. Weiner (1990). 'Implicit options in forward contracts: empirical estimates from the petroleum market.' Review of Futures Markets $9, \# 1$, pp. 1-14.

Phillips, Gordon M., and Robert J. Weiner (1991). 'Trading performance in forward markets: information vs. normal backwardation,' Krannert Graduate School of Management, Purdue University, Paper 1016, November. 
-Sas, Blanche (1987a). 'The legal aspects of the-15-day Brent market, I.' Journal of Energy and Natural Resources Law 5, \#2, pp. 109-133.

Sas, Blanche (1987b). 'The legal aspects of the 15-day Brent market, II: the proposals for structural change.' Journal of Energy and Natural Resources Law 5, \#3, pp. 182-201.

Shleifer, Andrei, and Lawrence H. Summers (1990). 'The noise trader approach to finance,' Journal of Economic Perspectives 4 (Spring), pp. 19-33.

Telser, Lester (1981). 'Why there are organised futures markets.' Journal of Lay and Economics 24 (Apri1), pp. 1-22.

Telser, Lester, and H. Higginbotham (1977). 'Organised futures markets: Costs and Benefits.' Journal of Political Economy 85 (October), pp. 969-1000.

Weiner, Robert J. (1989). 'The WTI Futures market and the Brent forward market: a comparative analysis.' In $0 i 1$ and Money: Coping with Price Risk through Financial Markets, by Kathryn M. Dominguez, John S. Strong, and Robert J. Weiner, Cambridge: President and Fellows of Harvard College.

Williams, Jeffrey (1987). 'Futures markets: a consequence of risk aversion or transactions costs?' Journal of Political Economy 95 (October), pp. 1000-1023.

'World crude' (1993). Weekly Petroleum Arqus 23, \#24 (21 June), p. 12. 
APPENDIX: NONPARAMETRIC TESTS OF FORECASTING ABILITY (cont inued)

Shosha

TRADER

POSITION

FUTURES PRICE MOVEMENT

short

long

down

214

up

total

455

471

total

669

506

961

1432

sum of conditional probabilities $=.98$

$p$-value $=.57$

Trading Company

TRADER

POSITION

short

FUTURES PRICE MOVEMENT

down

long

294

up
310

total

total

434

528

604

728

960

$836 \quad 1564$

sum of conditional probabilities $=1.03$

$p$-value $=.39$

Unknown

TRADER

POSITION
FUTURES PRICE MOVEMENT

$\begin{array}{lrrr} & \text { down } & \text { up } & \text { total } \\ \text { short } & 301 & 324 & 625 \\ \text { long } & 399 & 486 & 885 \\ \text { total } & 700 & 810 & 1510\end{array}$

sum of conditional probabilities $=1.03$

$\mathrm{p}$-value $=.40$

\section{Wall Street}

TRADER

POSITION 
APPENDIX: NONPARAMETRIC TESTS OF FORECASTING ABILITY (continued)

Shosha

TRADER

POSITION

$\begin{array}{lccr} & \text { FUTURES } & \text { PRICE } & \text { MOVEMENT } \\ & \text { down } & \text { up } & \text { total } \\ \text { short } & 214 & 257 & 471 \\ \text { long } & 455 & 506 & 961 \\ \text { total } & 669 & 763 & 1432\end{array}$

sum of conditional probabilities $=.98$

$p$-value $=.57$

Trading Company

FUTURES PRICE MOVEMENT

TRADER

$\begin{array}{lrrr} & \text { down } & \text { up } & \text { total } \\ \text { short } & 294 & 310 & 604 \\ \text { long } & 434 & 528 & 960 \\ \text { total } & 728 & 836 & 1564\end{array}$

sum of conditional probabilities $=1.03$

$p$-value $=.39$

Unknown

TRADER

POSITION
FUTURES PRICE MOVEMENT

$$
\text { down }
$$

301

399

700 up

324

486

810 total

625

885

1510

sum of conditional probabilities $=1.03$

$\mathrm{p}$-value $=.40$

Wall Street

TRADER

POSITION
FUTURES PRICE MOVEMENT

$\begin{array}{rrr}\text { down } & \text { up } & \text { total } \\ 210 & 244 & 454 \\ 315 & 408 & 723 \\ 525 & 652 & 1177\end{array}$

sum of conditional probabilities $=1.03$

$\mathrm{p}$-value $=.41$ 